\title{
Chapter 7 \\ This fragile present: \\ Verfremdung as a strategy of memorial in the work of contemporary South African artists
}

\section{Nancy Dantas}




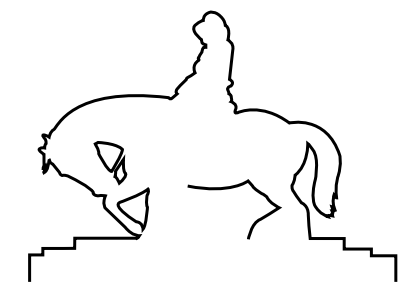

How soon people become bored with the making and unmaking of history, Grekov thought, remembering the hundreds of thousands who had taken to the streets to watch the first monuments fall.

(Vladislavic 1996)

I n their climatic, widely cited visual essay Statues Also Die, partly censored until 1968 (Fraiture 2016, 47), auteurs Chris Marker (director and writer), Alain Resnais, (co-director), Ghislain Cloquet (cameraman), and Guy Bernard (composer) juxtapose a striking and haunting array of displaced artifacts in European gardens and museums, developing a shared anti-colonial argument. To them, African art (was) at death's door and its artifacts, arrested in colonial mausoleums, demanded removal from the asphyxiating and deadening site of the colonial museum. Still visually impressive to us today, this stark black-and-white visual essay, composed of jarring still and moving images, begins with a pronouncement written by Marker and delivered by Jean Négroni in his matter-of-fact, staccato radio voice, intonated to command attention and extend authority and finality, veracity and gravitas to the documentary's initial assertion: "when men die, they enter into history. When statues die, they enter art. This botany of death is what we call culture" (Marker \& Ashby 2013, 431). It is not this essay's intention to provide a comprehensive reading and analysis of Les Statues, but rather to propose this 1953 documentary as an overture to thinking and envisaging how cultural objects can gain a new charge, one of unsettling and upending systems, particularly the systems of colonialism that arguably persist to this day. To those 
of us who study museums and curating, Les Statues usefully brings the camera into the (ethnographic) museum to analyse how objects are regarded, providing a window of opportunity to discuss how these cultural institutions domesticate time and place at a distance, providing, as Matthias de Groof has written, a "categorization of otherness in order to define the self" $(2010,31)$.

In Les Statues, Marker deplores the manner 'negro' artifacts that have been cannibalised by the west to become 'inauthentic' objects, constrained "to perform an act they were not meant to be performing" (Fraiture 2016, 48). Although current and acute in advocating the need for repatriation, Marker's argument is intolerably flawed to us today in its ideal of return to a 'pure' signifier called 'Africa' - an overly romanticised "country where every form had its signification, where the gracefulness of a curve was a declaration on love to the world" (De Groof 2010, 32) and to a(n) (imaginary) space where people exist in timeless bliss. In so doing, Marker forecloses the possibility of any exchange or dialogue with this place he considers lost to us, and which I would add as a corrective, has historically never been cut- off, isolated or without history. In effect Marker, like his antagonist, the ethnographic museum, does little to restore, but rather seems to emphasise impossibility, muteness, loss and death. Graver yet, he denies multivocality and the capacity of discourse to the continent and its production, still speaking with white patriarchal authority, through Négroni, for a mute people, in a mode that is not entirely dissimilar to the one adopted by the Musée de l'Homme, the Museum of the Belgian Congo in Tervuren, the British Museum and the Pitt River Museum and their conservators.

I propound instead that we consider Les Statues, and by extension, the displacement of cultural artifacts by way of critical intervention, as productive moments of verfremdung, that is, moments where artifacts that seem severed, neutered, resolved, categorised, and "known" become unsettled and highly charged once again. Ernst Bloch tells us that the word verfremden ("to estrange") is not old, but difficult to translate. 
Using Grimm as his source, he tentatively states that its first use in literature was in the 1842 novel Neues Leben by Bertold Auerbach:

In the novel, the parents feel verfremdet - that is, deeply wounded - because their children speak French, which the parents do not understand, in their presence. Presumably, the parents are being discussed; they feel estranged, treated as if they were not present. (Bloch 1970, 121)

To this, Bloch adds the concept of Verfremdungseffect, which he provides as the displacement or removal of a character or action (or object) out of its usual context, so that the character or action (or object) can no longer be perceived as wholly self-evident.

Through this, the scales fall from one's eyes, unveiling an instance of "exempla docent, although only by means of indirection" (ibid., 121). Displacement leads to revelation. To paraphrase Bloch further, the distant, the out-of-way, the displaced into heights reflects back and leads to an understanding of present reality. 


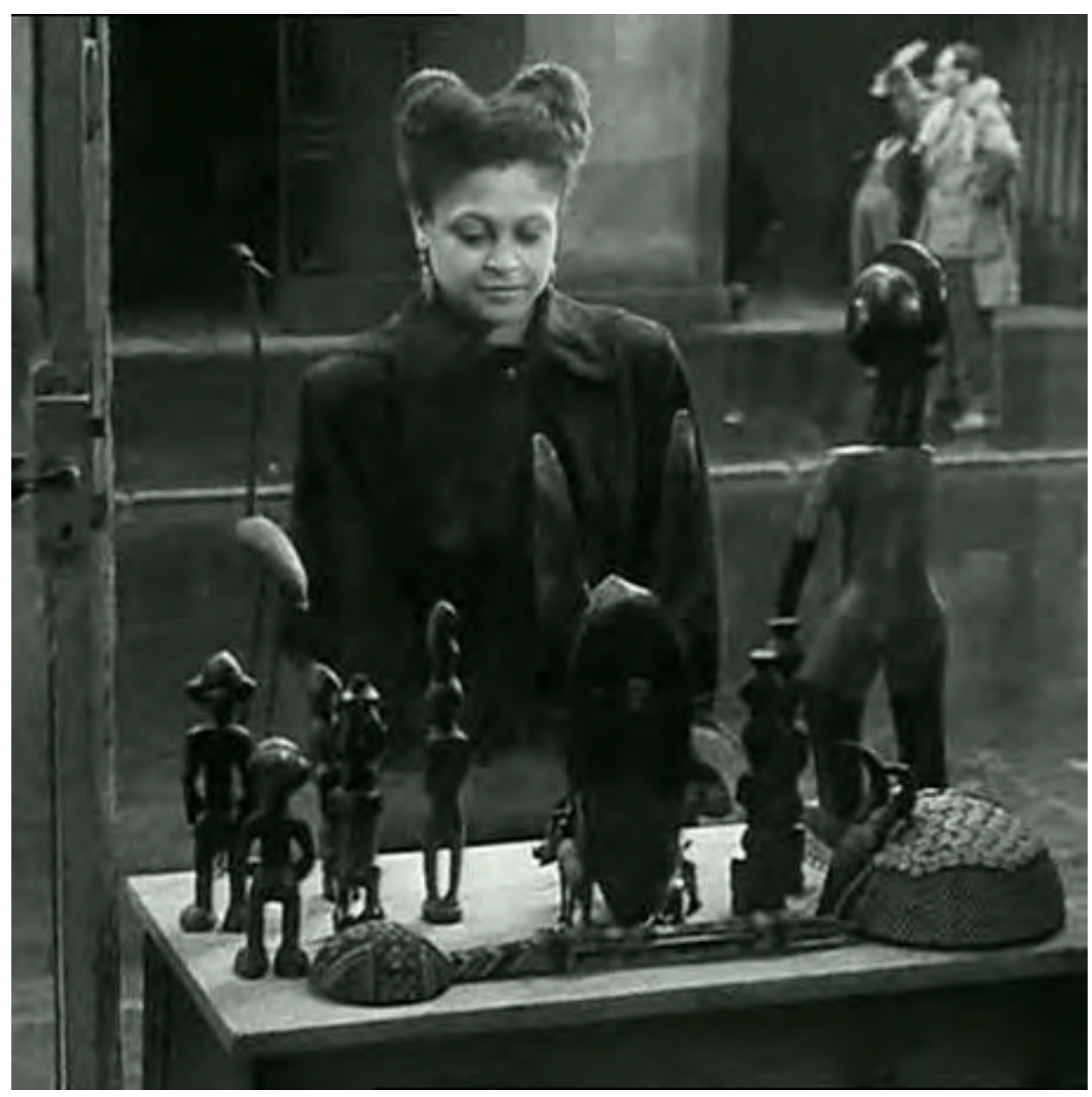

Figure 7.1. Still from Statues Also Die. [Black and White $35 \mathrm{~mm}$ film]. Chris Marker \& Alain Resnais. dir. France: Tadié Cinéma. 1953

Art arguably affords us ways of seeing what lies embedded and hidden, of perceiving differently and across time. Through the artist's dysphoric gaze, the previously invisible becomes visible, the absent becomes present, and the normalised, the homogenised, the classified within an existing dominant or hegemonic cultural system becomes displaced, estranged and haunted. This is no alchemy but rather the work of the politicised, cognisant, archaeological, decolonial and arguably depatriarchal approach of some artists. Through their work, and how they engage with "hot" monuments (Bellentani \& Panico, 2016), relations of visibility and invisibility, and the voluntary and many 
times willed blindspots of history are teased out. ${ }^{1}$ In this chapter, I will be looking at how a small number of artists, both contemporary and modern, engage with monuments, employing strategies of verfremdung within the built environment, seen by them as personifications or embodiments of the forces that condition and shape our times. These artists, culled from different generations and geographies, are Lungiswa Gqunta, Sikhumbuzo Makandula, Haroon Gunn-Salie and Leonard Tshela Mohapi Matsoso. They work with histories of trauma, albeit from different angles and with different approaches, in specific mediums which help to inform their, and by extension, our thoughts and perceptions of the cultural and lived landscapes we inhabit. The list of artists I have provided is not extensive but illustrative and indicative, in other words, incomplete and speculative. I would like to maintain and honour this open-endedness as it respects the present tide of revision and revulsion, which has not passed, and to which may other artists are likely to contribute. The text that follows is informed by Benjaminian fragmentation, and as such, prioritises and values plurality and rupture. It takes shape as a collection of fragments - a mosaic - and presents itself to readers through a series of interruptions and cinematic jump cuts.

I suggest that we commence with the eldest artist of all, the late Leonard Tshela Mohapi Matsoso, an underexposed champion of South African modernism, celebrated at the Bienal de São Paulo in 1973 with a Ciccillo Matarazzo Award. ${ }^{2}$ Despite this significant recognition, imparted to him at the surprising age of twenty-four by an international jury

$1 \quad$ Federico Bellentani and Mario Panico (2016, 34-35) distinguish between hot and cold monuments. The terms are somewhat self-explanatory. As they write, "in general terms, 'hot' monuments can elicit in users uncomfortable or even traumatic emotions. They can stimulate fierce political debates that may result in forms of conflict and resistance at a social level (...). Conversely 'cold' monuments convey meanings that have become widely shared by a large part of users (...) Cold monuments are peacefully integrated into the everyday practices of users that perceive them as ordinary built forms. This is the case with monuments that have turned into neutral landmark or mere meeting points." Originally monuments are not erected as hot or cold: "accepted monuments can turn into sites of resistance as well as controversial monuments can increasingly become accepted and mindlessly experienced during the routine of everyday life."

2 Readers should note that I have drawn on previously published material. See http:// wrongwrong.net/artigo/the-duty-of-decolonization-or-heeding-the-spectres-in-themuseum-and-as-archive 
comprised of five international critics and museum directors (António Bento, Robert Delavoie, Lu Ke King, Jiri Kotalik, and Donald Baum), Matsoso's career never catapulted as one would expect from such an accolade, stifled by the muting context of apartheid South Africa and its all-too-compliant emissaries, together with the reinforcing perversions of modernism itself which placed 'African', or worse yet, 'Bantu' art at the service of its mostly white, mostly male exponents.

Matsoso, an artist who diligently trained from a schooling age at Polly Street Art Centre (Miles, 2004:73), spent a significant part of his production envisioning the sculptural and monumental form. His work was displayed in groundbreaking exhibitions that have fallen deaf to the ears of history, perhaps due to the fact that they were arranged by the apartheid dispositif, being the rather spooky sounding "Cultural Section of the Department of Information" which had no intention of exalting or exhorting Black South African artists, but rather one of boxing, diminishing and thus effectively segregating and belittling their work. A case in point is the group exhibition, held from March 25 to May 16 of 1976 at the Brooklyn Museum and adjoining Brooklyn Public Library, "the first group exhibition in the United States of Black South African artists" (Potgieter 1976, 17). It included Matsoso's work under the broad category "graphic art." According to Stefanie Potgieter, in an article published in the June edition of Bantu, a journal expressly meant for a white readership, the "almost eight-week long exhibition of 16 tapestries and 90 graphic works of 10 artists was seen by nearly 250000 people".3 The article, in true apartheid style, as with all totalitarian memorycontrolling regimes, fails to mention the names of these artists, thus excising them from their due place in history.

Possibly owing to the influence of his peers and instructors, particularly Ezrom Legae who succeeded Sydney Kumalo at Polly Street in 1965, a young and one would imagine curious and impressionable Matsoso was

3 According to the editorial of October 1978: "BANTU [which had changed title to Progressus] continued as a publication mainly for White (sic) readers, in both English and Afrikaans." According to this same editorial, as overseas demand for the publication increased, in February of 1962, the two languages were separated and Bantu appeared in English and Afrikaans respectively. 
taken by the production happening around him, creating a body of work which would also gravitate to the sculptural and often monumental form, emulatinghis peers and their interest in three-dimensional work. Although portraiture was a component of the study programme at the Centre as much as life drawing (Miles 2004, 88), the sculptural prevailed amongst its learners (and instructors) and was thus to become a constant in the drawings of Matsoso. "Polly Street Art Centre cultivated an awareness that art was not only mimesis but a tool for expression", Elza Miles (2004, 10) writes, and in Matsoso's case, or so I posit, his output of drawings were a resistive response to the oppression he was subject to - one need only look at his titles to get a sense of the hardship he and his fellows faced $^{4}$-but more significantly to us, and within our chosen framework, his work discreetly countered the normalisation of an absence: the denial of the Black monument and Black cultural history in the South African landscape, providing us today with a window to number of blueprints for potential monuments, rendering his production arguably contemporary in its political and conceptual acuity.

Six years after having received an award for his drawings in São Paulo, Matsoso was recruited yet again by the city of São Paulo for an edition of the biennial that is commonly known as the 'bienal dos prémios' or biennial of accolades. The idea of the biennial was to provide an overview of the first fourteen editions and showcase work that had been awarded over these successive years. Although Matsoso is listed in the catalogue as a recipient in 1973, and even though he specifically produced a suite of drawings for the biennial in 1979 at the behest of his gallery, in conjunction with the South African government, his work was not exhibited (together with a tapestry by Marguerite Weavind, with visual artist Larry Scully as commissioner), as had originally been planned. "South Africa's participation in the 1979 Sao Paulo Biennale was cancelled due to political reasons shortly before the exhibition was held" according to the Director General of the Information Service of South Africa, in several letters written to consuls in the United States

4 Titles like Helpless, Helpless, a drawing from 1972, located in the Constitutional Court art collection, or Agony, one of the drawings presented at the Bienal de São Paulo in 1973. 
at the request of the National Executive Council of the South African Association of the Arts (heretoforth SAAA) to find alternative venues for the work produced by Matsoso and his fellow exhibitors. Despite the country's repeated attempts at rapprochement, namely in 1982 and 1984, Brazil's Ministry of Foreign Relations, otherwise known as Itamaraty, together with certain countries, in particular India, vetoed all attempts at South African participation and the country would not participate again until 1994.

It is conceivable that the government "acquired" the Matsoso suite of drawings, together with the Marguerite Weavind tapestry ${ }^{5}$ for the Pretoria State Theatre to console the artists, or perhaps itself for this embarrassing diplomatic rebuttal. I am reluctant to state that Matsoso's work was purchased. It was in effect sponsored by the South African Information Service at most. According to the SAAA's expense report, Matsoso received R300 for materials whereas Marguerite Weavind received ten times the amount for the production of her tapestry, paid over to the artist via a state grant managed by the SAAA.

Before finding a permanent home in what is today known as the South African State Theatre, Matsoso and Weavind's work travelled to the United States as a result of much diplomatic maneuvering. ${ }^{6}$ The suite of five drawings he produced for São Paulo, later exhibited in Houston and at the 'Festival of Two Worlds' or Spoletto Festival in South Carolina in 1980, were fierce and magisterial. ${ }^{7}$ Reproduction in

5 This was a 3-metre-high and 7 metre long mohair tapestry, designed by Judith Mason, consisting of five different sections depicting the Garden of Eden with two large angels whose wings, according to the official description, ended in five angel faces. Allegoric forms such as snakes, trees and flowers were included. The work I imagine and admittedly conjecture, by way of its sheer size, would have intentionally been included to overshadow and outshine Matsoso's drawings, indirectly enacting a symbolic battle of faiths and races, between Christian and traditional, colonial and autochthonous, European and African beliefs.

6 Until recently, Matsoso's suite was to be found in the lift foyer. The suite was removed in a general rehang of the collection and is currently in held in the theatre vault.

7 According to Michael Brown (2000), the Spoletto Festival was born in 1958 on the impetus of composer Gian Carlo Menotti and his vision: to unite two cultures and two art worlds, that is, the European and the American. The festival is mostly known for opera and theatre performances. According to correspondence between James T. Kerney, the festival manager in 1979, and the Ambassador of South Africa, Donald B. Sole, artists who participated in past festivals included Alberto Burri, Jean Cocteau, Willem deKooning, 
book form betrays their scale and impact. Measuring approximately $166 \times 85 \mathrm{~cm}$ each, the figures they depict are strikingly monumental. Of the five drawings, three relate directly to the legend of Nongqawuse. For apartheid South Africa, the story of Nongqawuse was dismissed as mere 'foolish folk tale', but for many today, and I would speculate Matsoso too, this real-life event bespeaks of the resoluteness, faith and selfless lengths and sacrifices that the Xhosa people committed to in order to save themselves from colonial expansion. ${ }^{8}$

It was in 1856, three years after bovine pleuropneumonia arrived in the Cape aboard a ship carrying Friesian bulls at Mossel Bay (Peires, 1987:45) with the additional aggravation of a severe drought that Nongqawuse, a young Xhosa girl, had a vision that the ancestors were preparing themselves to return to life, salvaging her ailing population with the offering of new cattle and a revived land (Ashforth 1991, 581). In order to prepare for their coming, this young seer was told all the Xhosa must burn their crops and slaughter their cattle. When the ancestors failed to arrive by the predicted date, despite reluctance in some quarters, most of Nongqawuse's people had decided to destroy their livelihoods to appease the ancestors. An estimated 40000 people starved to death as a consequence (Peires 1987, 43). The survivors, forced to seek assistance in the British Cape Colony, were driven into the service of the colonialists. Unsurprisingly, under the leadership of Governor Sir George Grey, the colonial administration brutally exploited and capitalised on the situation and vulnerability of the Xhosa people, who saw the power of the chiefs broken and their lands seized for European settlement (Ashforth 1991, 581).

Helen Frakenthaler, David Hockney, Robert Indiana, Robert Motherwell and Andy Warhol.

$8 \quad$ It should be noted that Nongqawuse's prophecy was preceded by that of Nxele, who lived from about 1780 to 1820, at a time when Xhosa society was coming under increasing pressure from within as well as without. According to Jane Hodgson, sometime between 1816 and 1818, Nxele, an igogo credited with second sight, offered his people a course of action that was grounded in traditional worldview, yet charged with a new source of power, claiming that he had seen a vision. "Dalidiphu appeared to me and spoke to me saying, 'Tell my people to prepare themselves for action. They must kill all dun-coloured cattle.' He will cause all the dead to rise from their graves. They will come out of the sea, ready and armed to the teeth" (Hodgson 1985, 25). 
Although there is much to be said of this complex event which has served different agendas over time, I would argue that Nongqawuse's vision is not located in the past, but in the future-present, creating a compelling haunting and stirring amongst her followers - an intertwined dream of becoming, return and regeneration - a decolonial and anti-colonial desire - which Matsoso, with his Brazil suite, wished to tap into and possibly share with his Portuguese-speaking counterparts.
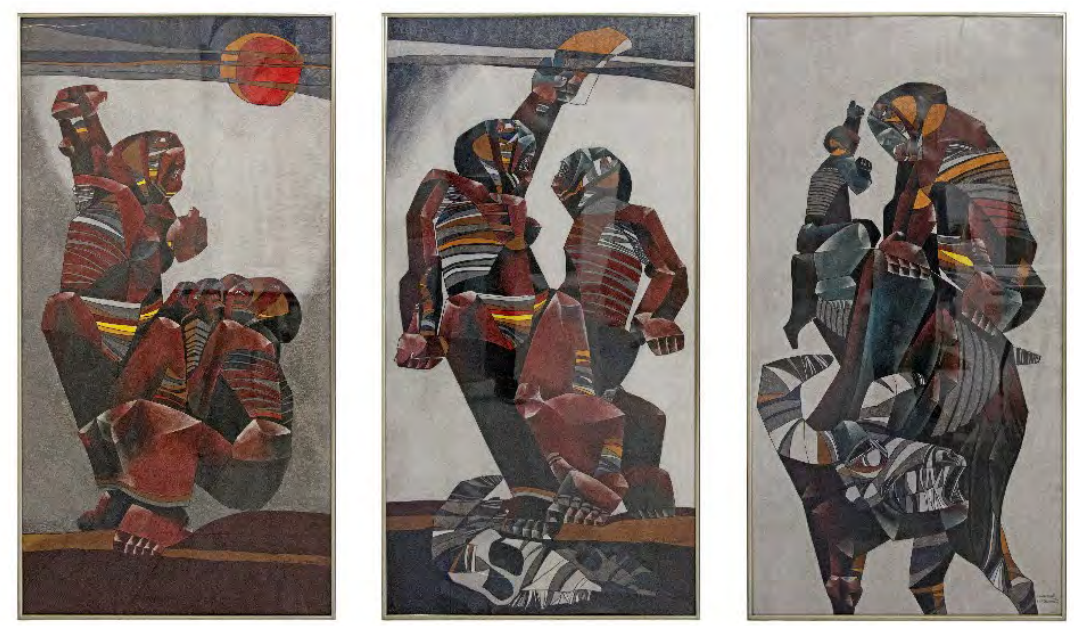

Figure 7.2. Matsoso, Leonard Tshela Mohapi. Nongqawuse (sic) I, II, III. [Oil pastel on paper]. $166 \times 85 \mathrm{~cm}$ each. 1979

Each of Matsoso's panels portrays a monumental Nongqawuse, a seer, liminal being and niece of Mhlakaza, associated with the Xhosa cattle killing in different scenes. In his novel, The Heart of Redness, Zakes Mda envisions Nongqawuse as unkempt and with the appearance of a waif. He further adds to his description, "in the manner of all great prophets she seemed confused and disoriented" $(2000,59)$. Unlike Mda, Matsoso portrays Nongqawuse in the first panel as a grandiose figure, addressing a group of four crouched, grimacing subjects, who like her, are smeared in traditional red ochre. They appear to attentively draw on her words under a crimson, apocalyptic African sun. A long cloud of grey stretches across the sky, possibly caused by the burning fields, which she has called her people to ignite. Nongqawuse's right arm is raised; her fist clenched in colonial-cum-apartheid defiance and leadership as she 
addresses her hungry, broken kin. Like others included in the scene, the exposure of the lines of her thoracic cage are exacerbated, alluding not only to the drought of the summer of 1855-1856 (Peires 1987, 45) but also, and more importantly, to the diseased cattle and loss of land brought about by English colonisers. The scene encapsulates the emotion and despair of people whose entire wellbeing rested with its cattle, and who, as Peirce writes, "loved each beast individually". Thanks to colonial settlers, who bought with them this invisible deadly disease, cattle owners and shepherds were forced to watch their animals putrefy from the inside out (Peires 1987, 47). Moving on to the second scene, Nongqawuse stands erect with another figure, their conjoined bodies indissociable. At their feet lies the carcass of a dead animal. There would have been many more corpses, but Matsoso, I would argue, chose to represent the familial unit and its individual connection to each animal. Nongqawuse touches and is connected to both earth and sky. In this scene, she holds the sun in her hand; a possible representation of the popular expression "ulihambe lingashoni" - to catch or hold the sun in an act of defiance, resilience and glory. In the third and last panel of the triptych, Nongqawuse rests atop of a living Nguni bull. Her back is bent from exhaustion. The skies have cleared, and she is again one with animal. Her partner however is represented divorced from her in the background, pleading to an absent, possibly Christian God. Still within reach, not all has been lost.

In addition to the above triptych, two other works around the veiled theme of colonial-cum-apartheid resistance were included. In the vertical, almost life-size work Man and Beast, an amaXhosa man wrestles a giant, toothed monster with a poised, diminutive spear. One might argue that the giant crocodile depicted in the battle alludes to Die Groot Krokodil (Afrikaans for The Big Crocodile), a nickname used for P.W. Botha, the then prime minister of South Africa and first executive state president from 1984-1989. In the other horizontal panel, titled Mabalele, the crocodile has almost dominated its human prey. Although pinned down and trapped by the reptile's heavy grey body, this warrior looks death - read the apartheid oppressor - squarely in the face. 
It should be noted that Matsoso's technique was eximious for an artist working under dire conditions shared by most Black artists under apartheid. Living and working mostly from Soweto, he did not have access to electricity or a conventional and expansive studio space. This would understandably have conditioned the scale of work he was able to produce. Nevertheless, his workmanship demonstrates the supersession and overcoming of these otherwise impossible working conditions. His drawings deliver exceptionally striking tones and a palette that renders the human form as perennial, colossal and rocklike. If South Africa was void of monuments to the Black individual, Matsoso was defiantly erecting primordial and perennial figures on two-dimensional surfaces, which looked as though, and suggested that they had been designed, and here lies the crux of my argument, to be carved and commemorated in stone. Rather than engage with these works as drawings on paper, I suggest we look at them as blueprints for monuments and imagine ourselves walking and engaging with their presence. I believe this is what Matsoso desired to impress upon his viewers, both then and now, and that this is what renders them fearsome and unsettling, ultimately leading to their removal from the State Theatre walls where they were once hung.

If Matsoso was responding to a void, a wave of young Black artists today are engaging and struggling in various ways with a landscape still populated and dominated by apartheid's wreckage, be this its institutions or monuments; questioning, troubling and estranging their untouched presence, their embedded ideologies and divisive legacy in present-day South Africa. Katharyne Mitchell argues that "traces of memory left in the landscape point to the political, cultural and economic forces which cohered at that moment to produce a vision of the way a (dominant) society perceived itself and represented itself to itself" $(2003,448)$. She further writes, "during moments of major political disjunctures, when national and individual identity is challenged in fundamental ways", such as in 'post-apartheid' South Africa, "the politics of memory rises to the fore, and (settled) monuments, in particular, become sites of great conflict" (ibid., 448). 
The artists I will be looking at from this point on, or so I argue, plant "seeds of difference" (ibid., 451) in these lieux de mémoire or sites of memory, underlying the continuities and discontinuities they embody. Pierre Nora $(1989,19)$ tells us that lieux de mémoire are created by a play of memory and history. As I see it, today's generation, in this fragile present, are productively calling attention and staging the difference and opposition between (Black) memory and (settler) history, in a battle with white settler monuments and their meaning. Memory and history, as Nora $(1089,8)$ writes, are far from synonymous:

Memory is life, borne by living societies founded in its name. It remains in permanent evolution, open to the dialectic of remembering and forgetting, unconscious of its successive deformations, vulnerable to manipulation and appropriation, susceptible to being long dormant and periodically revived. History, on the other hand, is the reconstruction, always problematic and incomplete, of what is no longer. Memory is a perpetually actual phenomenon, a bond tying us to the eternal present; history is the representation of the past. Memory, insofar as affective and magical, only accommodates those facts that suit it; it nourishes recollections that may be out of focus or telescopic.

This generation of emerging artists has taken it upon itself to wrestle with the memories of these places and their genius loci, in other words, "the geniuses we locate there" (Mayerfeld Bell 1997, 813). Theirs is a bitter struggle, one that is part and parcel of an informal project of resistance to normative memory production. By way of their counterpractice, these artists refuse to accede to the scripting of history in the format of a once-dominant minority power, creating works which speak to a different interpretation of historical events. 


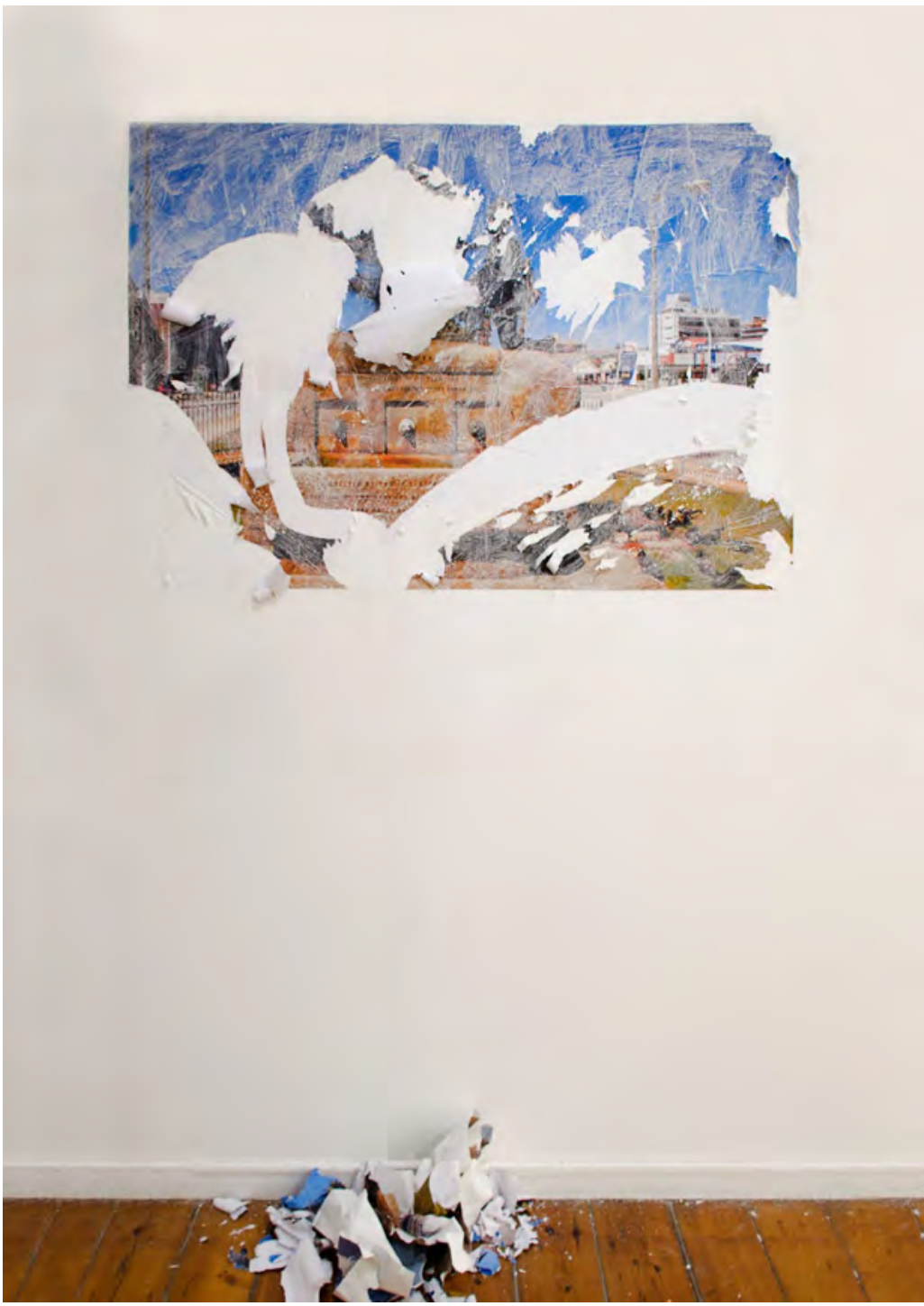

Figure 7.3. Gqunta, Lungiswa. Horse Memorial I. [Paper, wheat paste and water]. 2017

Horse Memorial I by Lungiswa Gqunta is a rather inconspicuous intervention considering the artist's remaining expansive production. Somewhat reminiscent of the décollages of Wolf Vostell and Jacques Villegle, Gqunta presents a lacerated and gnashed colour print of the contested Horse Memorial, seen in profile from its location in Port Elizabeth. Looking at this modest work of a torn poster-sized image, the indices on the wall are not of careful peeling, but rather represent the desire to rip, peel and tear apart, signalling the determination, 
anger and scorn which have fuelled the artist's desire to see this image removed from the wall, and metonymically, from public space and our shared cultural landscape. This life size, 3-ton bronze statue, which is still to be found erect in Port Elizabeth, is dedicated to the thousands of horses that died on active duty in the Second Anglo-Boer War between 1899 and 1902, and depicts a soldier kneeling before his horse, holding a drinking bucket under its muzzle. According to Major Tylden, cited by G.R. Duxbury, the British Army supplied 520000 horses and 150000 mules of which 350000 horses and 50000 mules perished. The losses of the 'Burgher Forces' were not given, but the total probably exceeded 150000 (Duxbury 1968, n.p.). In a description dating back to 1964, Richard Buncher states that the statue "has a touchingly tender, dramatic quality" $(1967,139)$. Sculpted by Joseph Whitehead, Buncher $(1967,139)$ further adds that its author "worked with inspiration while the citizens of Port Elizabeth, led by Harriet Meyer, contributed considerable concern and much money".

Originally erected in 1905, exactly 110 later, this kneeling soldier was toppled by a group of 30 men dressed in red (Marias \& Wilson 2015). Gqunta, I posit, like these unidentified men, wishes to underscore and give voice to the history elided by the monument and its promulgators, affording us a different, decolonial reading of the symbol. In her thesis, she reminds us that with the horses came the Bubonic plague, a disease hitherto unknown to the land, and with it, death and a reason to dislocate and uproot countless Black families. ${ }^{9}$ According to architect Franco Frescura, British military authorities imported large numbers of horses from Argentina to fight the Anglo-Boer

In her highly commendable text on the absent history of the ubiquitous horse, social historian Sandra Swart reminds us that the horse (Equus caballus) was not indigenous to South Africa, but was introduced by white settlers. Swart traces this long history to Jan Van Riebeeck and his desire to reshape the landscape and change the native ecosystem. In order to remove bushes, plough the soil, cut down shrubs and trees, transport lumber, sand, clay and firewood, horses were much needed for the 'landscaping' that was required. After much arguing with the VOC, they were eventually brought from Java, much to the dissatifaction of Riebeeck who found the breed (known as the 'South East Asia Pony') to be light and insubstantial $(2007,127)$. Swart further writes: “The horses together with a pack of hunting dogs - were imported, to a certain extent to inspire terror in the Khoisan, who were beginning to initiate raids upon the settlements. Van Riebeeck argued that a watch of twenty riders would prove a suficiente deterrent. On 7 June 1660, the settler authorities udes horses to display settler ascendancy." 
War. With their fodder came infested vermin which carried Bubonic plague (Spinage 2012, 1352). Between 1901 and 1903, most of South Africa's major towns, Port Elizabeth included, recorded outbreaks of the disease. As Frescura in an undated entry on South African postal history writes:

... although its spread affected all sectors of the population, it was the black community who bore the brunt of the Plague Health Regulations. In 1902, most of Port Elizabeth's black suburbs were demolished, the personal belongings of their residents were arbitrarily destroyed, and restrictions were imposed upon inter-town travel.

It was at this time that the racially segregated suburb of New Brighton (Gqunta's hometown) was established, some $8 \mathrm{~km}$ from the city centre, to house families that had been displaced during the outbreak. According to John Iliffe $(1987,115)$, others were forced to settle on other peri-urban freehold land such as Korsten, a suburb named after Frederick Korsten, one of the first traders to settle in Algoa Bay.

To date, little to no interest has been shown by the media in understanding the public contestation or even the possibility that this monument could actually repress a history of hurt and loss, depicting the toppling somewhat blindly as disgraceful and shameful. Dr Beverley Roos Muller, in an online article titled Horse memorial attack makes no sense, surprisingly fails to evoke or acknowledge this history, possibly unaware of the connection between the horse, Bubonic plague and the forced and racialised displacement of local populations, which Gqunta seeks to obliquely evoke through her work. ${ }^{10}$ As such, rather unsurprisingly, a year after it was dismantled,

10 Professor Myron Echenberg in his treaty Plague Ports: The Global Impact of Bubonic Plague 1894-1901, provides an account of the arrival of the plague in Cape Town and posits that it was this epidemic in particular that acted as the catalyst, setting in motion the phenomenon of urban racial segregation which has characterized and defined South Africa to this day. Echenberg points the emergence of these policies to William Simpson, professor of hygiene at Kings College, London, who accompanied the pandemic around the British Empire. Simpson, considered an expert at the time on the disease, happened to be in Cape Town in 1901. Although his purpose was to study typhoid fever among troops fighting in the Transvaal, he availed himself to the Plague Advisory Board. According to Echenberg, "Simpson's so-called expertise in plague matters stemmed essentially from his limited clinical observations and selective reading rather than 
undisclosed members of the Nelson Mandela Metropolitan University sculpture collective trenchantly and stubbornly repaired the soldier, placing it defiantly back, according to The Herald (6 May, 2016). The greatest irony is possibly one of the memorial's inscriptions, which reads: "The greatness of a nation consists not so much in the number of its people or the extent of its territory, as in the extent and justice of its compassion." Little compassion, it should be said, has been shown to those living in Korsten or New Brighton and their history of displacement and dispossession, brought on originally by these otherwise innocent beasts and their pest-ridden fodder.

Looking at an old apartheid-era map, one would see the outline of the Ciskei to the East of Port Elizabeth and its Horse Memorial. No longer delineated by cartographers, this place, a former 'Bantustan', is the seat of Sikhumbuzo Makhandula's attention. To be more precise, in his video titled Isigidimi, Makandula visits Ntaba kaNdoda, a modernist-inspired monument created by the Honourable Chief Lennox Sebe as part of a grand plan to create a distinct Ciskeian identity which had not existed until then, and one that was needed to legitimate independence in 1981. Franco Frescura, ten years after this date (1992, n.p.) writes:

laboratory research. His few experiences convinced him that in South Asia, barefooted Indians became infected with the plague from contaminated earth" $(2007,281)$. Simpson's approach to the disease was basically a sanitarian one. He blamed local populations for the spread of the disease, and "showed neither sympathy for nor understanding of the structural causes of overcrowding and squalid housing" (ibid.). In conjunction with Dr Alfred John Gregory, his junior colleague, he advocated the establishment of segregated locations for the poorer class of Europeans and people of colour. "Simpson paternalistically proclaimed the need for 'ethnic zoning' throughout British possessions in Africa and Asia and recommended a neutral belt of open unoccupied country of at least 300 yards in width between the European residences and those of the Asiatic and African" (ibid., 282). Fuelled by Simpson's opinion, Cape Town applied the standard control measures employed in most other sites, with the difference that Black Africans were taken as the major target of these measures, especially vector control or vaccination. Public health officials showed little regard for Black African possessions, ordering most of their goods burned as opposed to sanitized (ibid., 285) when forcefully removing the Black African population, living mostly in District Six and One, to a site in Uitvlugt (today known as Ndabeni). In addition to crippling travel restrictions, Black Africans were forced to take Haffkine's vaccine, which "was said to have been of dubious value and to have caused significant side effects" (ibid., 289). According to a report in the Cape Times of April 4, Gregory was asked if it was true that several people who had been inoculated had had to have their arms amputated! 
When the Ciskei opted for 'independence' in 1981 under the South African Government's 'Bantustan' policy, it did so with the consent of only a small minority of its population and against the specific recommendations of its appointed consultants. In the process, it inherited a legacy of poverty unequalled in modern-day southern Africa. The Ciskei is also unique among South Africa's rural 'homelands' in that it has absolutely no basis upon which to claim a separate ethnic, cultural or linguistic identity, no separate Ciskeian identity, no separate Ciskeian culture, nor is there a Ciskeian language. Instead its people are intrinsically bound within the larger Xhosa identity.

Ntaba kaNdoda formed part of Sebe's plan to invent that identity which involved the creation of an annual holy day, one which Frescura likens to the Swazi first-fruits celebration. An audience was guaranteed on this day by members of the Ciskeian Civil Service who were obliged to attend under the threat of dismissal. The national shrine cost approximately R860 000 and was funded by compulsory deductions made from the salaries of civil servants. In addition to the phallic monument, conceived by Sebe following a somewhat telling visit to Mount Massada in Israel, a 'Hero's Acre' was incorporated where the bones of Chief Maqoma, a Xhosa leader who opposed white colonial rule, were reinterred after having been 'found' in an unmarked grave on Robben Island. 


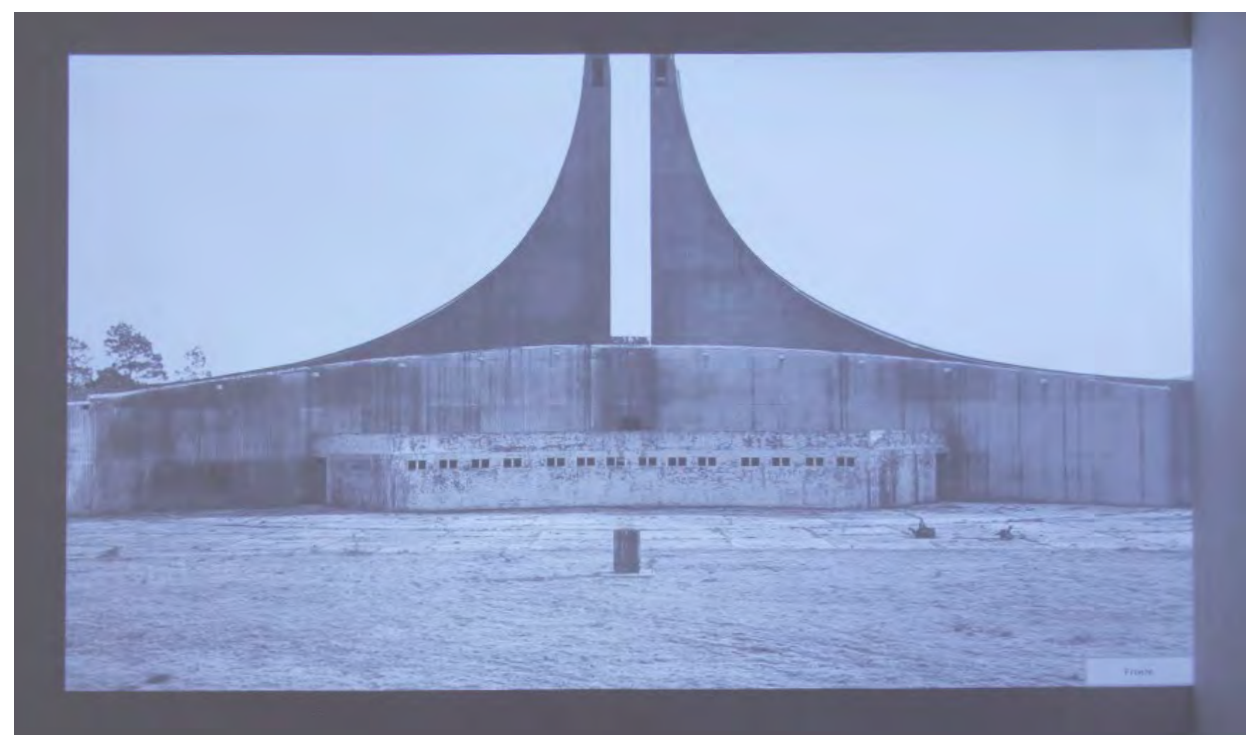

Figure 7.4. Makhandula, Sikhumbuzo. Still from Isigidimi $\left(06^{\prime} 02^{\prime \prime}\right)$. [Short film]. 2016. Photograph: Carlos Marzia Studio.

Over the course of his six-minute video, Makhandula traverses the indoor and outdoor spaces of the hauntingly deserted and divisive Ntaba kaNdoda monument, providing views of this nationalist and fracturing ruin and wound. Throughout, Makhandula personifies a messenger from another world, performing what appears to be a cleansing ritual. Dressed as 'The Messenger' in a long tunic and conical-looking hat, he treads carefully, burning incense in a thurible as he traverses the space methodically and rhythmically. Makhandula's mock performance serves to evoke devotion and sacrifice. The repeated motion of the burner recalls the hypnotisation of the masses, a common denominator amongst nationalist and fracturing monuments worldwide, erected to celebrate the forefathers, pioneers and heroes of the nation. Ntaba kaNdoda, now an abandoned carcass, like those of other monuments of division, still occupies the landscape and the Eastern Cape's visual horizon, despite the fact that Sebe's bust has been dethroned. These are the persistent physical marks, etched into the landscape, of a past with no immediate undoing.

Visitors to the South African pavilion at the Venice Biennale in 2015 would have encountered an anti-monumental work by Haroon 
Gunn- Salie. It is no coincidence I have chosen a work from a biennial as the last, for my intention is to also bring this analysis full circle, evoking and summoning the ghost of Matsoso and the parallel history of biennials as one which like the monuments that surround us, remains largely unchanged. But I digress ... The unsuspecting Italian visitor, on entering the first section of the pavilion would have encountered a set of dismembered aged hands, the one clenched, the other holding a walking stick, placed centrally on a high wall, with intent and purpose above eye level. On busy days, foreign and unsuspecting visitors were likely to walk unawares beneath the red (blood soaked) hands of Jan Van Riebeeck, possibly even taking an obligatory selfie shot and posting it to social media. Cast by Haroon Gunn-Salie and Bevan Thornton on Freedom Day in 2015 (Dunbar-Curran 2015), the ghostly amputated hands are a direct impression (from the Latin imprimire, to imprint) of the Jan Van Riebeeck statue located in Cape Town's CBD. The slightly outstretched hands as seen on location, proudly and affectedly take in and hold the view of a buzzing Adderley Street and awe-inducing Table Mountain.

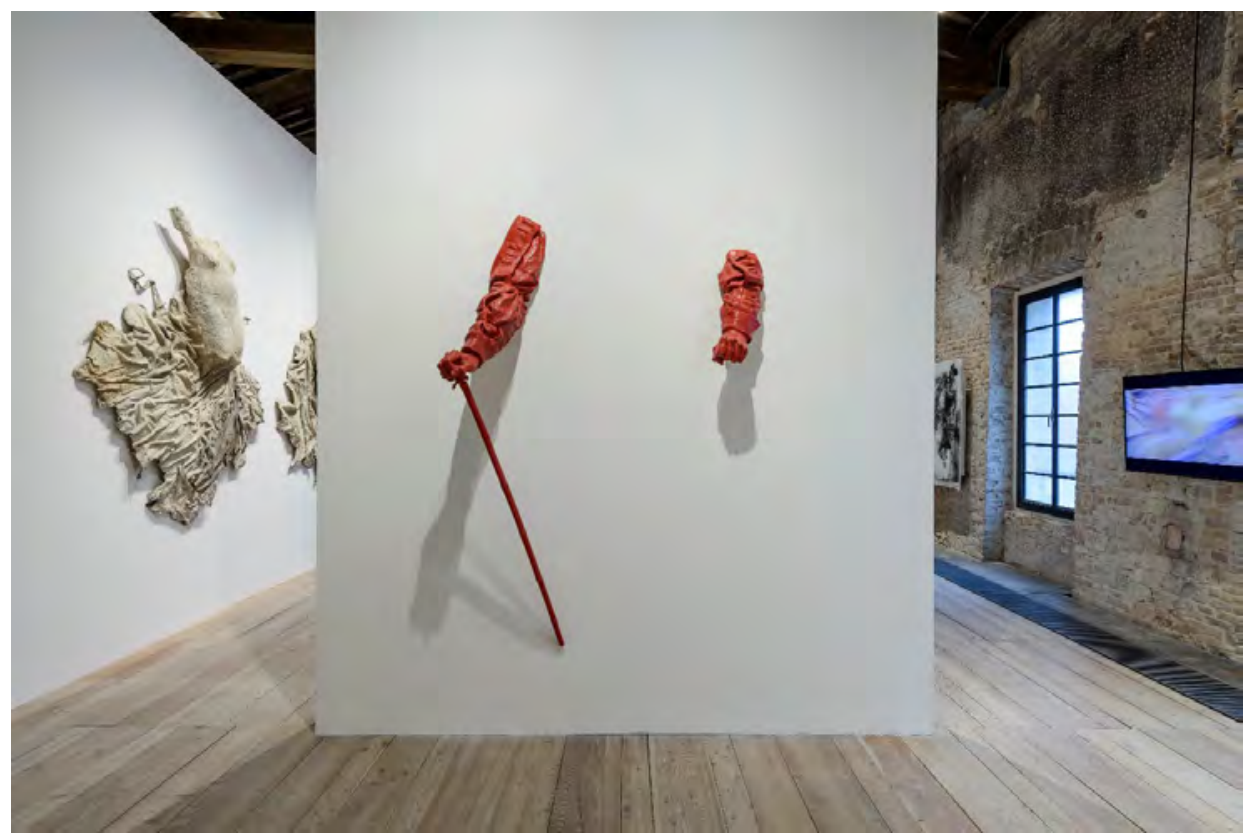

Figure 7.5. Gunn-Salie, Haroon \& Bevan Thornton. Soft Vengeance (Jan van Riebeeck). [Reinforced urethane cast]. 2015 
Unbeknownst to many visitors, the original statue was commissioned by arch-colonialist Cecil John Rhodes in 1896 as a gift to the City of Cape Town. "With his back to the shoreline, left fist clenched in determination, (Riebeeck) stands gazing on Table Mountain as if asserting a claim to the land", writes Leslie Witz $(2003,43)$, establishing a significant parallel between the pose witnessed in the statue and a mid-19th century canvas titled Arrival of Van Riebeeck 1652 by Charles Davidson Bell where Van Riebeeck is portrayed "as part of British colonial identity". According to Phillida Brooke Simons, this painting is one of several works Bell based on extracts from the journal of Van Riebeeck. According to Brooke Simons $(1998,93)$, "(i)t shows the Dutch commander with his henchmen, all of them hatted, helmeted and flag-flying, greeting a group of scantily clad Khoikhoi with Devil's peak in the background".

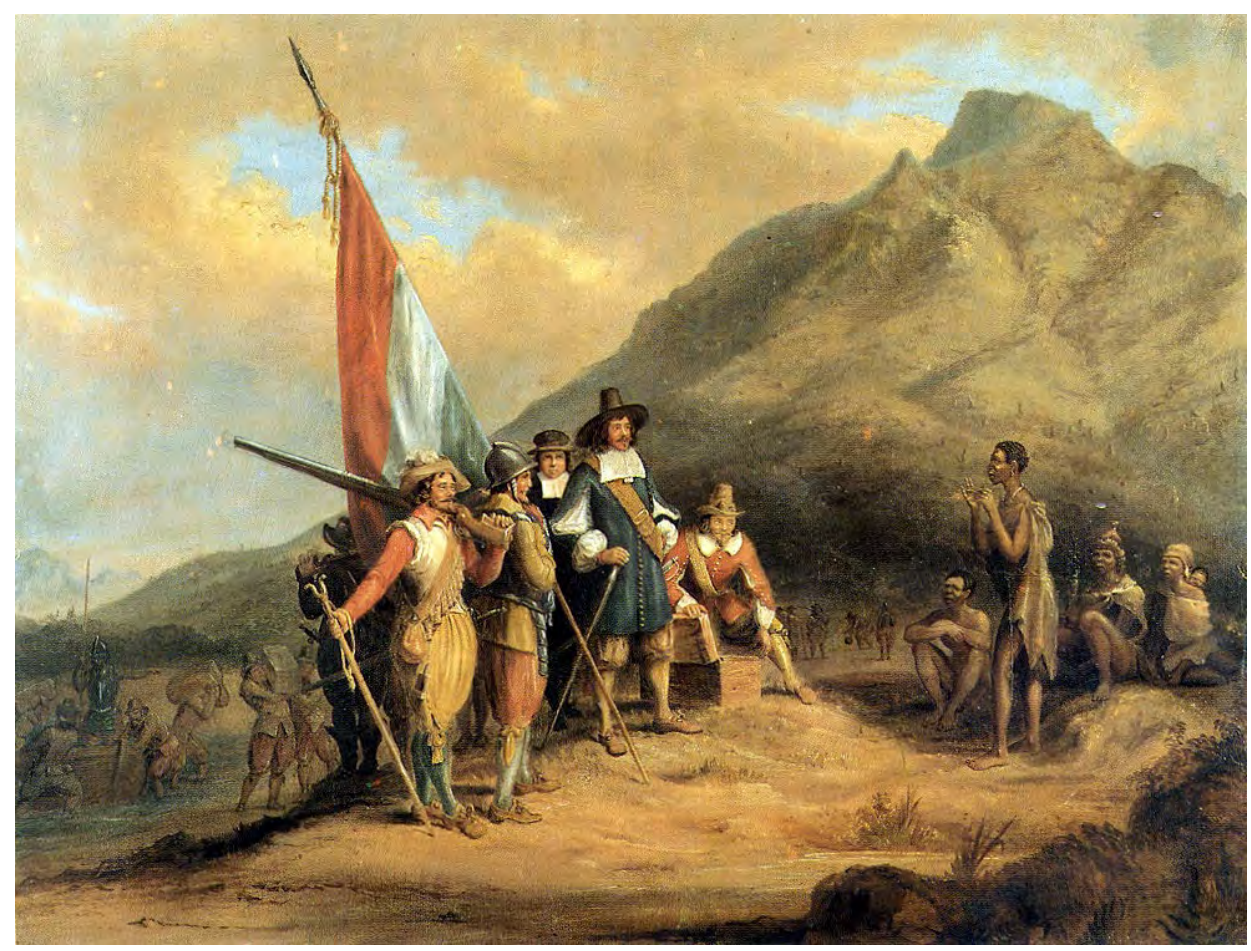

Figure 7.6. Bell, Charles. The Landing of Van Riebeeck, 1652. [Oil on canvas]. $79,5 \times 92 \mathrm{~cm} .1850$ 
Witz $(2003,42)$ tells us that Bell was a draughtsman who arrived in Cape Town from Britain in 1830. He partook in several expeditions to the interior and took up several clerical posts within government, eventually becoming surveyor general. About the aforementioned painting, Witz (42) critically writes:

Bell's painting, particularly of the landing, blends his background of draughtsmanship - the attention to ethnographic detail and the need to pinpoint people into carefully defined locations - with the English picturesque tradition and the Dutch historical movement of the nineteenth century. In the English tradition, broad landscapes were observed from a distance, with an emphasis on re-creating images on the "middle plane," situated between a shadowy foreground and a background receding in the distance. It is in this middle plane that the historical event is located and Van Riebeeck appears, attired in a long flowing English-style jacket, carrying a walking stick with a large silver top, accompanied by Cromwellian-type soldiers with guns and an enlarged version of the Company flag. Set slightly farther aback, and blending into the background of trees and mountains, are a group of local Khoi inhabitants dressed in what appear to be tattered rags, all but one of them seated as they greet Van Riebeeck and his colleagues. The stark contrast of the apparel, the spatial location of the two parties, and the portly pose of Van Riebeeck as opposed to the almost humble greeting of the Khoi group turn the landing into an archetypical first encounter (...) Van Riebeeck, in his English guise of a rural landlord, is reinforced as the initiator of the civilizing mission in southern Africa.

To this reading, I would add another historical parallel, between Bell and his contemporary Delacroix, namely his Orpheus Comes to Civilize the Savage Greeks and Teach Them the Arts of Peace. To my mind, the similarity of the mountain in the backdrop is striking, establishing a bridge that connects the two creations across space, highlighting the colonising and "civilizing" ideology in which they both commune. Both present a balanced group of figures involving a 'hero' bathed in light. In the case of Van Riebeeck, not only does the sun shine where he steps, illuminating the path before him, thus suggesting the righteousness of 
his mission, but Van Riebeeck's garments and those of the henchmen closest to him, presented as a pyramidal grouping with Van Riebeeck at the summit, radiate a golden, warm light.

John Tweed, the sculptor of the Van Riebeeck statue on Adderley Street, like Bell, appears to have drawn on the same sources and ideology, in his portrayal of a rather contrived and academic rendering of Van Riebeek. Ironically, Bell, Tweed and others after them, in their making of the myth and topos of the landing and Van Riebeeck as one of the 'first fathers' of the 'nation', were more than likely to have used a portrait from the Rijksmuseum collection, mistakenly identified as being that of Van Riebeeck, but in fact one of another Dutchman, a man presumed to be Bartholomeus Vermuyden.

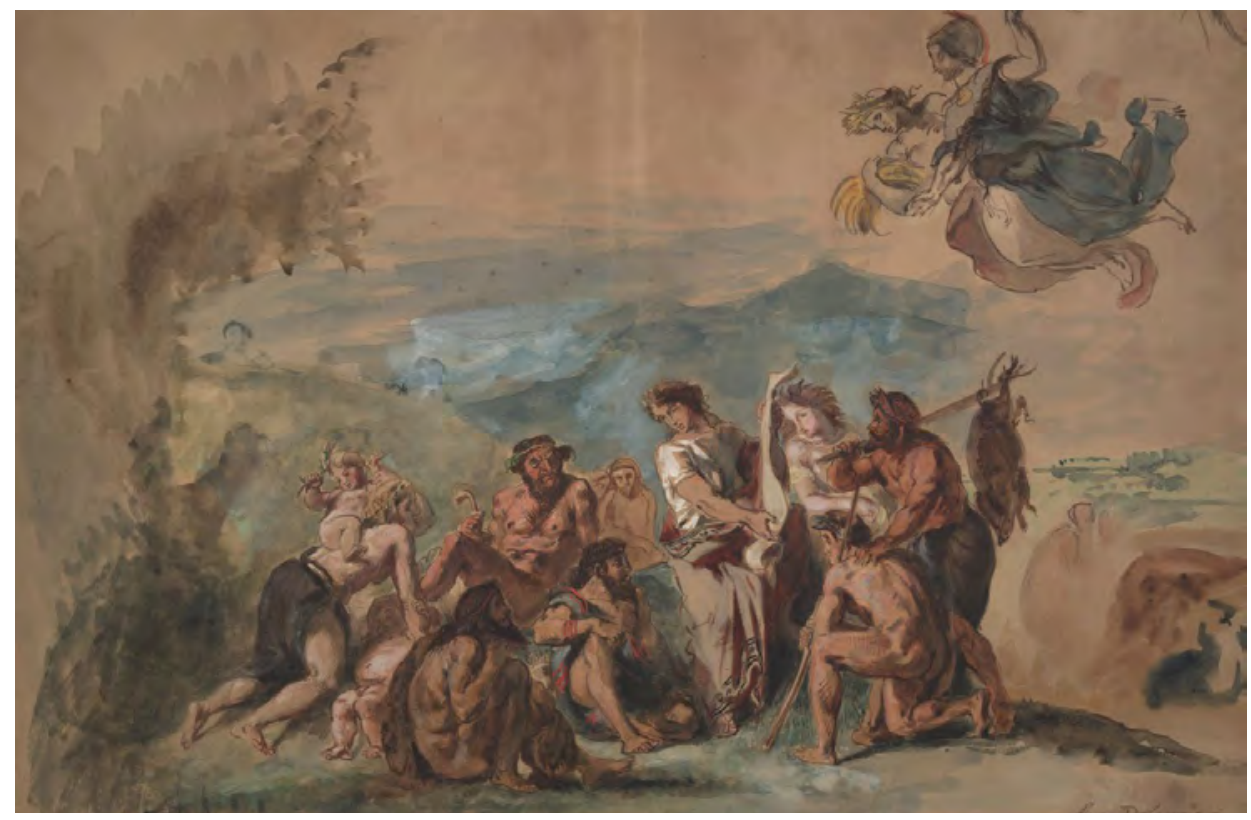

Figure 7.7. Delacroix, Eugene. Orpheus Civilizes the Greeks. [Brush and watercolour and white body colour over graphite]. 1842. Photograph: Yale University Art Gallery

Despite the irony of this mistaken identity perpetuated through time, of one thing we can be sure, with Van Riebeeck began a long history of theft and land dispossession. According to Petrus Deport and Tshepo Lephakga (2016, n.p.) from the University of South Africa: 
Jan van Riebeeck and the Dutch East India Company were not philanthropists out to uplift the indigenous people; they were, like all capitalists and traders, out to make money by whatever means necessary. The VOC was a mercantile capital-driven company, uniting a number of Dutch commercial undertakings, backed by the Dutch government and military that developed into one of the largest and most profitable commercial companies of the seventeenth and early eighteenth centuries. Their mercantilist mentality was what characterised this first systematic strategy of accumulation by European powers in South Africa. Accordingly, this mercantilist mentality dictated that the VOC was allowed to trade on the land they occupied and that if their economic interests were threatened by any of the indigenous people, they could use whatever means necessary to protect their interests.

As Lianne van Kralinger (2017, 249) has stated, Van Riebeeck was in fact commanded to annex the best and fattest portions of land for the company: "You shall after landing inspect the most convenient spots for lands and pastures, and erect signs of having taken possession." It was with Van Riebeeck that a painful and shameful history of "accumulation by dispossession" (Harvey 2004) begun and rent on local populations.

But let us return our attention to Gunn-Salie and his Venice installation, now that the ideological, dialogical, and diachronical footing of this monument of discontent has been given. In putting up the severed hands of Van Riebeeck, I posit Gunn-Salie wishes us to consider this monument from the past as still active in the present, and part of what Natalia Kryzanowska (2016, 469), drawing on Gramsci, calls a form and agent of 'spatial hegemony' whereby domination and rule are achieved. The Van Riebeeck monument thus becomes, not only for Gunn-Salie, who was born in Cape Town, but many other like-minded individuals, a "key foci of struggle" (Kryzanowska 2016, 469) between a different and opposing interpretation of a past whose elements are embodied in/through the monument itself. Zubeida Jaffer (2015, n.p.), a writerin-residence based at the University of Free State, in an opportune opinion piece published at the height of the \#RhodesMustFall 
movement in 2015, offers a counter-narrative to the one provided by the apartheid history text books, which still prevails in certain circles today. Jaffer evokes the counter-memory of Autshumato (from the Goreinghaikona) when recalling the 1652 landing. It was he who encountered the European delegation and lead the first of the two Khoi-Dutch wars, together with Gogosa and Doman, leaders of the Gorinhaiqua, aided by the Goranchouqua, "whom the Dutch called the 'Tobacco Thieves"' Jaffer (my emphasis) states,

"Van Riebeeck continues to be presented as one whom we should value. His statue occupies centre stage at the foot end of Adderley Street, the main street in our city. He spent eight years of his life on these shores and we hold him up as an example to our children who know nothing about Autshumato, the great KhoiSan leader."

By presenting Van Riebeeck's dismembered hands, Gunn-Salie aligns himself with this divergent decoding of the monument, articulating though his installation, in particular the degree of elevation and angle of interaction, how apartheid and settler colonialism continue to manipulate and condition social reality, even though we are led to believe that these colonial corpses are dead. Like these surreal, ghostly hands that eerily reach out to spectators from behind the wall, apartheid too remains undead, conducting and orchestrating reality invisibly, from 'behind' the institution's impeccable white walls.

Undressed, unhealed and largely untouched, South Africa's wounds remain discernible to the seers of monuments and effigies and the power they silently but effectively wield. This too is the case in Spain, where communities still aspire redress and acknowledgement. Although distinct and distant in many ways, I believe the shared pain and historic trauma inflicted on the peoples of Spain and South Africa - embodied and consistently evoked by uniquitous monuments justifies some parallel.

Until March 17, 2005, a seven-metre-tall bronze esquestrian statue of General Franco (horses again!) was to be found undisturbed on Juan 
de la Cruz Square in Madrid, Spain. This image, like many others commissioned before it formed part of an extensive propaganda machine, "designed and implemented in an effort to legitimize (Franco's) rule" (Hadzelek, 2012:154). Along with it, newsreels, public displays such as posters, busts, and statues were erected all over Spain from the early days. According to Hadzelek, citing Jesus de Andrés as her source, the first was installed in Salamaca in October 1937. Iconography was a sign of Franco's obsession with his own image and reflects the cult of the leader essential to fascist ideology. "What sets Spain aside", she writes, "is the persistence of the iconography in the public sphere for decades after the dictator's death, as well as its society's inability or lack of willingness to, until recently, seriously address the human rights human abuses of the Franco era" (Hadzalek 2012, 155).

Following the Spanish Law of Historical Memory passed in 2007, which called for the removal of all Francoist symbols from public buildings and spaces, on the above date, an understated and unpublicised removal of the caudillo, mounted on his horse, took place. Hadzelek $2012,160)$ relates the event of the toppling as having taken place:

(...) in the early hours of the morning, starting at 2 am, supposedly to avoid disturbing the traffic. To pre-empt confrontation, there was heavy police presence and the spectators were told to disperse. Except for a few shouts and fascist salutes, it was uneventful. Until the next day, that is when people started gathering around the empty pedestal and adorned it with flowers and a Spanish flag, some praying on their knees. A demonstration of protest of the removal, organized by the Spanish fascist party Falange, was attended by approximately 700 people who assembled in front of a large portrait of Franco that had been placed in front of the empty pedestal. One of the iconic images of Franco as crusader was beamed onto the scaffolding that the authorities had placed there, projecting a virtual presence of Franco where the physical monument of him had stood before. This demonstration was reported in major international media outlets, 
complete with the image of the fascist salute, and was followed by a heated debate in the Spanish media.

I have intentionally chosen the example of Spain to evoke and establish an analogy with our fragile present in South Africa. Perhaps South Africa, like Spain, will take 32 years or more to pass its own 'Law of Historical Memory', calling for the removal of all settler monuments from public buildings and spaces. Until then, civil society will continue to dispute the overwhelming presence of the patriarchal white pioneer and statesman, and the disavowal this signifies of people's pain and dispossession, glorified on campuses, hilltops, in public gardens and squares. Only when such a law is set in place and enforced will the doors of history be opened. Until then, South Africa, like Spain, will have traded justice, rehabilitation and compensation of victims for the 'spirit of reconciliation' and a 'peaceful' transition. By setting aside the immediate past and moving forward, the Spanish nation has slowly come to see this political and social compromise as a 'pact of forgetting, associating amnesty laws of the 1970s with amnesia (amnesia), silence (silencio), forgetting (olvido) and disremembering (desmemoria) (ibid., 163). The Spanish example, together with the artists analysed, urges South Africans to take a different path, a revolutionary path, the path of remembrance and justice. Until then, history will be lost and occluded, and monuments made markers of untruth.

I end with Jules Michelet's edict, "the Revolution has for her monument: empty space." As I write this, a number of Confederate statues in the US are being removed from their plinths. There is clamour, there is contestation, there is tension, but revolution and the uprising of the dispossessed, the repressed and the invisible can never silent. 


\section{Bibliography}

Ashforth, Adam.

"The Xhosa Cattle Killing and the Politics of Memory." Sociological Forum 6, no. 3 (1991): 581-592. Accessed 24 June 2016, http://www.jstor.org/stable/684521

Bellentani, Federico. \& Mario Panico.

"The meanings of monuments and memorials: toward a semiotic approach." Punctum 2, no. 1(2016): 28-46. DOI: 10.18680/hss.2016.0004

Bloch, Ernst.

"Entfremdung, Verfremdung: Alienation, Estrangement." Translated by Anne Halley \& Darko Suvin. The Drama Review 15, no. 1(1970): 120-125. Accessed 3 July 2017, http://www.jstor.org/stable/1144598

Braun, Michael. 2000.

"Courting the Media: How the 1988 Spoleto Festival USA attracted media coverage." International Journal of Arts Management 2, no. 2(2000): 50-58.

Buncher, R.

1967. Some South African Monuments. Cape Town: Purnell.

De Groof, Matthias.

"Statues Also Die - But Their Death is not the Final Word." Image and Narrative 11, no. 1(2010): 29-46.

Delport, Petrus T. \& Tshepo Lephakga.

"Spaces of Alienation: Dispossession and Justice in South Africa." HTS Theological Studies 72, no. 1 (2016). Accessed 30 July 2017, http://dx.doi. org/10.4102/hts.v72i1.3567

Dunbar-Curran, Terri.

Molding Vengeance in Soft 3D. Cape Times, April 29, 2015. Accessed July 9 2017, https://www.iol.co.za/capetimes/arts-portal/visual-arts/molding-vengeancein-soft-3d-1851608

Echenberg, Myron.

Plague Ports: The Global Impact of Bubonic Plague 1894-1901. New York: New York University Press, 2007. 
Fraiture, Pierre-Philippe.

"Statues Also Die." Journal of French and Francophone Philosophy, 1(2016): 45-67. DOI 10.5195/jffp.2016.757

Frescura, Franco.

Branch Offices of Port Elizabeth, 1822-1910, 2017. Accessed 11 July 2017, http:// www.sahistory.org.za/franco/postal-history-branches-PE.html

Frescura, Franco.

Monuments and the Monumentalization of Myths. Paper presented at the History Workshop, University of Witwatersrand, Johannesburg, 18 July, 1992.

Gqunta, Lungiswa.

Stranger's Location: Interrogating Apartheid Spatial Legacies and the Idea of Home in New Brighton. MA thesis. Cape Town: University of Cape Town, 2017.

Hadzelek, Aleksandra.

Spain's pact of silence and the Removal of Franco's Statues. In Past Law, Present Histories, edited by Dianne Kirkeby. pp. 153-176, 2012. Accessed 29 July 2017, http://www.jstor.org/stable/j.ctt24h3t8.12

Harvey, David.

"The 'New' Imperialism." Accumulation by Dispossession 40 (2004): 63-87. Accessed 12 October 2017, http://socialistregister.com/index.php/srv/article/ view/5811\#.Wd8D14Vxupd

Hodgson, Janet.

"A Study of the Xhosa Prophet Nxele (Part I)." Religion in Southern Africa 6, no. 2 (1985): 11-36. Accessed 26 June 2017, http://www.jstor.org/stable/24763725

Iliffe, John.

The African Poor. New York: Cambridge University Press, 1987.

Jaffer, Zubeida.

The 8 years of Van Riebeeck. IOL News. February 13, 2015. Accessed 23 July 2017, https://www.iol.co.za/news/opinion/the-8-years-of-jan-van-riebeeck-1817889

Kryzanowska, Natalia.

"The discourse of counter-monuments: semiotics of material commemoration in contemporary urban spaces." Social Semiotics 26, 5 (2016): 465-485, http:// dx.doi.org/10.1080/10350330.2015.1096132 
Marais \& Wilson, G.

EFF members dismantles (sic) Horse Memorial. The Herald, 6 April, 2015. Accessed Accessed 12 July 2017, http://www.heraldlive.co.za/news/topnews/2015/04/06/eff-members-dismantled-horse-memorial/

Marker, Chris \& Lauren Ashby.

"The Statues Also Die." Art in Translation 5, no. 4 (2013): 429-438. Accessed 28 June 2017, http://dx.doi.org/10.2752/175613113X13784777319807

Mayerfeld Bell, Michael.

"The ghosts of place." Theory and Society, 26, no. 6 (1997): 813-836. Accessed 26 July 2017, http://www.jstor.org/stable/657936

Mda, Zakes.

The Heart of Redness. Cape Town: Oxford, 2000.

Michelet, Jules.

History B356: French Revolution and Napoleon, 1847. Accessed 9 September 2017, http://www.indiana.edu/ b356/texts/Michelet.htm

Miles, Elza.

Polly Street: The Story of an Art Centre. South Africa: Ampersand Foundation, 2004.

Mitchell, Katharyne.

"Monuments, Memorials, and the Politics of Memory." Urban Geography 24, no. 5 (2003): 442-459. Accessed 26 July 2017, http://www.tandfonline.com/doi/ abs/10.2747/0272-3638.24.5.442

Molefi, R.K.

"Of rats, fleas, and peoples: towards a history of bubonic plague in southern Africa, 1890-1950." Pula: Botswana Journal of African Studies 15, no. 2(2001): 259267. Accessed 26 July 2017, http://pdfproc.lib.msu.edu/?file=/DMC/African $\% 20$ Journals/pdfs/PULA/pula015002/pula015002013.pdf

Nora, Pierre.

Between Memory and History: Les Lieux de Mémoire. Representations 26 (1989): 7-24. Accessed 13 March 2011, http:www.jstor.org/stable/2928520

The Herald. PE Horse Memorial Repaired, 6 May, 2016. Accessed 12 July 2017, http://www.heraldlive.co.za/news/2016/05/06/pe-horse-memorial-repaired/ 
Peires, Jeffrey B.

"The Central Beliefs of the Xhosa Cattle-Killing." The Journal of African History 28, no. 4 (1987): 43-63. Accessed 26 July 2017, http://www.jstor.org/stable/181448

Simons, Phillida Brooke.

The Life and Work of Charles Bell. Vlaeburg: Fernwood Press, 1998.

Spinage, Clive.

African Ecology-Benchmarks and Historical Perspectives. Berlin: Springer, 2012.

Swart, Sandra.

"Riding High - Horses, Power and Settler Society in Southern Africa, c. 1654-1840." In Breeds of Empire: The 'Invention' of the Horse in Southest Asia and Southern Africa 1500-1950, edited by Greg Bankoff \& Sandra Swart. Copenhagen: Nordic Institute of Asian Studies. pp. 123-139, 2007.

Van Kralinger, Lianne.

"Justice and the Company: Economic Imperatives in the Journal of Jan van Riebeeck (1652-1662)." In: Postcolonial Justice, edited by Anke Bartels, Lars Eckstein, Nicole Waller \& Dirk Wiemann. Leiden: Koninklijke Brill. pp. 243-260, 2017.

Vladislavic, Ivan.

Propaganda by Monuments \& Other Stories. Cape Town: David Philip, 1996.

Witz, Leslie.

Apartheid's Festival: Contesting South Africa's National Pasts. Bloomington: Indiana University Press, 2003. 